\title{
ADROPIN - POTENTIAL LINK IN CARDIOVASCULAR PROTECTION FOR OBESE MALE TYPE 2 DIABETES MELLITUS PATIENTS TREATED WITH LIRAGLUTIDE
}

\author{
Tina Tičinović Kurir ${ }^{1,2}$, Tanja Miličević ${ }^{1}$, Anela Novak ${ }^{1}$, Marino Vilović $^{2}$ and Joško Božić ${ }^{2}$ \\ ${ }^{1}$ Department of Endocrinology and Diabetes, Split University Hospital Centre Split, Croatia; \\ ${ }^{2}$ Department of Pathophysiology, University of Split School of Medicine, Split, Croatia
}

\begin{abstract}
SUMMARY - The aim of this study was to determine plasma adropin concentration and parameters of insulin resistance in obese male type 2 diabetes mellitus (T2DM) patients before and after 3 -month liraglutide treatment. In this interventional study, we enrolled 15 obese male T2DM patients with body mass index $(\mathrm{BMI})>35 \mathrm{~kg} / \mathrm{m}^{2}$, uncontrolled disease and $\mathrm{HbA}_{1 \mathrm{c}}>7.5 \%$, having previously taken taking two oral antidiabetic drugs. We modified their therapy to metformin and liraglutide for the next three months. After three months of liraglutide treatment, we observed significant decrease in body weight (from $111.5 \pm 18.7 \mathrm{~kg}$ to $109.2 \pm 17.5 \mathrm{~kg}, \mathrm{p}=0.016$ ) and BMI (from $40.9 \pm 7.3$ to $40.1 \pm 7.0$ $\mathrm{kg} / \mathrm{m}^{2}, \mathrm{p}=0.021$ ). Plasma adropin concentration increased significantly $(\mathrm{p}=0.003)$ compared with baseline. Fasting plasma insulin level decreased from $17.79 \pm 6.53$ to $13.38 \pm 3.51 \mathrm{mU} / \mathrm{L}(\mathrm{p}=0.002)$, fasting plasma glucose level decreased from $8.66 \pm 3.07$ to $7.41 \pm 2.21 \mathrm{mmol} / \mathrm{L}(\mathrm{p}=0.004)$ and $\mathrm{HbA}_{1 \mathrm{c}}$ decreased from $7.98 \pm 0.70 \%$ to $7.26 \pm 0.36 \%(\mathrm{p}=0.003)$. Insulin resistance presented as HOMA-IR decreased significantly from $7.30 \pm 5.19$ to $4.52 \pm 2.61(\mathrm{p}=0.002)$. Systolic blood pressure, lipid status, liver and kidney function improved, but not reaching statistical significance. Treating obese male T2DM patients with liraglutide resulted in a significantly higher plasma adropin concentration, significant weight loss and improved parameters of insulin resistance, i.e. decreased fasting plasma insulin, plasma glucose levels and HOMA-IR.
\end{abstract}

Key words: Diabetes mellitus type 2; Insulin resistance; Obesity; Adropin; Liraglutide; Endothelial cell dysfunction

\section{Introduction}

Nowadays, type 2 diabetes mellitus (T2DM) seems to be one of the most important public health challenges. Current estimates of its incidence are imprecise, only providing a rough picture, and probably underestimating the disease burden ${ }^{1}$. Dealing with T2DM implies coping with the complex chronic disease that demands lifelong medical and self care in order to prevent acute and delay chronic complications ${ }^{2}$.

Correspondence to: Assoc. Prof. Tina Tičinovic Kurir, $M D, P h D$, Department of Pathophysiology, University of Split School of Medicine, Šoltanska 2, HR-21000 Split, Croatia

E-mail: tticinov@mefst.hr

Received July 11, 2018, accepted January 24, 2020
Body mass index (BMI) has a strong relationship to insulin resistance and T2DM development. In obese individuals, the amount of substances involved in the development of insulin resistance is increased. The pathogenesis of T2DM development is based on the fact that pancreatic $\beta$-cells are impaired, causing a lack of blood glucose control. The development of T2DM becomes inevitable if the pancreatic $\beta$-cell failure is accompanied by insulin resistance ${ }^{3}$. T2DM increases overall mortality primarily due to cardiovascular disease, which is the major cause of morbidity and mortality among these patients. Further on, patients with poor glycemic control are at risk of developing microand macrovascular complications, unlike those who maintain tight glycemic control ${ }^{4,5}$. 
Ten years ago, Kumar et al. identified a new protein named adropin, which is believed to play an important role in metabolic homeostasis, insulin resistance prevention, dyslipidemia and impaired glucose tolerance $^{6-8}$. It is encoded by the ENHO gene (Energy Homeostasis Associated Gene) and its expression in the liver, heart, brain and coronary arteries is diet dependent $^{6}$. Results of the studies conducted so far show that the diseases resulting from metabolic syndrome, such as obesity, T2DM, non-alcoholic fatty liver disease, polycystic ovary syndrome, or cardiovascular disease are accompanied by significant changes in the concentration of this peptide ${ }^{8}$. Plasma adropin concentration is decreased in T2DM patients, especially those overweight or obese ${ }^{9,10}$. Moreover, adropin is a potent regulator of cardiovascular function and plays a protective role in the pathogenesis and development of cardiovascular disease ${ }^{11}$. It regulates endothelial cell function and its plasma concentration has been found to be lower in individuals with endothelial dysfunction, which seems to be an autonomous indicator of cardiovascular incidents in individuals with T2DM. Furthermore, adropin concentration and $\mathrm{HbA}_{1 \mathrm{c}}$ are shown to be independent risk factors for endothelial dysfunction in these patients ${ }^{12-14}$.

Diabetes mellitus type 2 is characterized by a reduced incretin effect and inappropriate glucagon levels, so the incretin-based therapy could provide beneficial effects, not only because of the antidiabetic effect but also for the favorable effect on body weight ${ }^{15,16}$. In 2010, the National Institute for Health and Care Excellence (NICE) issued guidance on the use of one of the incretins called liraglutide in $\mathrm{T}_{2} \mathrm{DM}^{17}$. Liraglutide is an analog of human glucagon-like peptide-1 (GLP1) and acts as GLP-1 receptor agonist (GLP-1 RA). Its efficacy in glycemic control has already been established. It increases insulin and reduces glucagon secretion, slows down gastric emptying, postpones carbohydrate absorption, and augments satiety ${ }^{18,19}$. The majority of T2DM patients on liraglutide treatment report more significant weight loss than those treated with other GLP-1 RA ${ }^{20}$. To assess the long-term effects of liraglutide on cardiovascular outcomes and clinically important events, the Liraglutide Effect and Action in Diabetes: Evaluation of Cardiovascular Outcome Results (LEADER) trial was initiated in $2010^{21}$. Trial results showed a lower rate of death from cardiovascular causes, nonfatal myocardial infarction, or nonfatal stroke among T2DM patients treated with liraglutide as compared to those on placebo ${ }^{22}$.

Considering the fact that T2DM patients are characterized with lower plasma adropin concentration ${ }^{9}$ and that liraglutide has a positive effect on both glycemic control and cardiovascular outcomes ${ }^{20-22}$, we decided to explore plasma adropin concentration in obese T2DM patients after three months of liraglutide treatment. As far as we know, this is the first report on adropin concentration in obese T2DM patients undergoing liraglutide treatment.

The aim of this study was to determine plasma adropin concentration and parameters of insulin resistance in male obese T2DM patients before and after 3-month liraglutide treatment.

\section{Materials and Methods}

This was a non-randomized, controlled, interventional study. The primary objective was to determine plasma adropin concentration and parameters of insulin resistance in male obese T2DM patients before and after three months of liraglutide treatment. Patients treated at Department of Endocrinology and Diabetes, Split University Hospital Centre from April 2017 to June 2017 were invited to participate in the study. Investigators had meetings with patients and explained the study nature, aim, potential hazards, and expected outcomes. The study was conducted according to the Declaration of Helsinki and Good Clinical Practice, with a written informed consent obtained from each participant. It was approved by Ethics Committee of the Split University Hospital Centre. Sampling was performed in 15 male obese T2DM patients with BMI $>35 \mathrm{~kg} / \mathrm{m}^{2}$, uncontrolled diabetes mellitus and $\mathrm{HbA}_{1 \mathrm{c}}>7.5 \%$. All the participants had previously received two oral antidiabetic drugs. In all cases, firstline agent was metformin, while second-line agent was sulfonylurea in 12 and dipeptidyl peptidase-4 (DPP-4) inhibitor in three participants. In our study, we modified their therapy, which now consisted of metformin (1000 mg b.i.d.) and liraglutide (Victoza ${ }^{\circledR}$, Novo Nordisk A/S, Bagsvaerd, Denmark) for the next three months. To improve gastrointestinal tolerability, the starting dose was $0.6 \mathrm{mg}$ liraglutide daily. After two weeks, the dose was increased to overall $1.2 \mathrm{mg}$ daily until the end of the study. 
In each participant, we observed anthropometric data, blood pressure, parameters of glucose metabolism, Homeostatic Model Assessment of Insulin Resistance (HOMA-IR) index and plasma adropin concentration at the beginning and after three months of the study. Anthropometric measurements included body height, weight, BMI, body circumferences (waist and hip), and waist to hip ratio (WHR). Body height was measured using a stadiometer with the investigator standing behind the participant. Subjects stood with their scapula, buttocks and heels resting against the stadiometer, the neck was held in a natural nonstretched position, the heels were touching each other, the toe tips formed a $45^{\circ}$ angle and the head was held straight with the inferior orbital border in the same horizontal plane as the external auditive conduct (Frankfort's plane). The horizontal arm of the stadiometer was lowered until it touched the scalp (anthropometric point vertex). Body weight was measured on a medical decimal scale with sliding weight, with a $\pm 250 \mathrm{~g}$ error margin. Patients were barefoot, only wearing their underwear. The weight was rounded up to the nearest $0.5 \mathrm{~kg}$. BMI was estimated by dividing weight $(\mathrm{kg})$ by height ${ }^{2}\left(\mathrm{~m}^{2}\right)^{23-25}$. Waist and hip circumferences were measured using a flexible non-elastic measuring tape. Individuals stood with their feet together and arms resting by their sides. Hip circumference was measured from the maximum perimeter of the buttocks. Waist circumference was taken as the plane between the umbilical scar and the inferior rib border. Each measurement was performed twice and the mean result was calculated ${ }^{26,27}$. Waist circumference was used to identify individuals with possible health risks based upon threshold values of $\geq 88 \mathrm{~cm}$ for women and $\geq 102 \mathrm{~cm}$ for men. WHR measurement is used to estimate visceral or android obesity. WHR was estimated by dividing waist circumference by hip circumference. The threshold WHR was $\geq 0.85$ for women and $\geq 1.00$ for men and was used as a criterion for android obesity. Abdominal circumference and WHR are good indicators of body fat distribution and cardio-metabolic risk ${ }^{27,28}$. Blood pressure was measured using a mercury sphygmomanometer with the corresponding cuff size (Riester desk model), following the WHO MONICA Protocol (MONItoring of trends and determinants in CArdiovascular disease and Protocol $)^{29}$. Patients were seated and relaxed for 5 minutes before the measurements were taken. Measurements were performed on the right forearm, at the position of the brachial artery by trained measurers. Values were noted with $\pm 2 \mathrm{~mm} \mathrm{Hg}$ accuracy. Two measurements were done, 5 minutes apart, and the mean value of the two measurements was used for analysis ${ }^{30}$.

According to the regular protocol, the same experienced biochemist took and analyzed blood samples obtained from the antecubital vein after 12-hour overnight fasting. Fasting blood samples were analyzed in the same laboratory, using the same method for each substance. The biochemist had no knowledge of the patient medical condition. Insulin blood levels were measured using the electrochemiluminescence immunoassays $\left(\right.$ Roche $^{\circledR}$ Diagnostics $\mathrm{GmbH}$, Mannheim, Germany). Enzymatic hexokinase photometric assay (Abbott ${ }^{\circledR}$, Chicago, IL, USA) was used to measure fasting plasma glucose and turbidimetric inhibition immunoassay (Roche ${ }^{\circledR}$ Diagnostics GmbH, Mannheim, Germany) to measure $\mathrm{HbA}_{1 \mathrm{c}}$ plasma levels. Plasma adropin levels were measured using an enzyme-linked immunosorbent assay kit (Phoenix Pharmaceuticals, Belmont, CA, USA) according to the manufacturer's instructions. Other laboratory analyses were performed according to the standard laboratory protocols. Insulin resistance score (HOMA-IR) was calculated using the following formula: fasting plasma glucose $(\mathrm{mmol} / \mathrm{L}) \times$ fasting serum insulin $(\mu \mathrm{U} / \mathrm{mL})$ divided by 22.5 .

Statistical analyses were performed using MedCalc for Windows, version 11.5.1.0 (MedCalc Software, Mariakerke, Belgium) statistical software. Continuous variables were expressed as mean \pm standard deviation, whereas categorical variables were expressed as whole numbers and percentages. Differences between baseline and after three-month treatment values were determined using Wilcoxon matched paired test. The level of statistical significance was set at $\mathrm{p}<0.05$.

\section{Results}

Fifteen male obese T2DM patients receiving therapy that consisted of metformin (1000 mg b.i.d.) and liraglutide (Victoza ${ }^{\circledR}$, Novo Nordisk A/S, Bagsvaerd, Denmark) were followed up for three months. Median age of the patients included in our study was 60 years, body weight (mean \pm standard deviation $[\mathrm{SD}]$ ) was $111.5 \pm 18.7 \mathrm{~kg}, \mathrm{BMI}\left(\right.$ mean $\pm \mathrm{SD}$ ) was $40.9 \pm 7.3 \mathrm{~kg} / \mathrm{m}^{2}$ and $\mathrm{HbA}_{1 \mathrm{c}}$ (mean $\pm \mathrm{SD}$ ) was $7.98 \pm 0.70 \%$. Baseline waist to hip ratio (mean $\pm \mathrm{SD}$ ) was $0.96 \pm 0.08$. 
Table 1. Anthropometric data

\begin{tabular}{|l|l|l|l|}
\hline Variable & Baseline* & $\begin{array}{l}\text { After 3 months } \\
\text { of treatment* }\end{array}$ & $\mathrm{p}^{* * *}$ \\
\hline $\begin{array}{l}\text { Age (years)** } \\
\text { Body height }(\mathrm{cm})\end{array}$ & $60(55-68)$ & $60(55-68)$ & 1.000 \\
$\begin{array}{l}\text { Body weight }(\mathrm{kg}) \\
\text { Body mass index } \\
\text { (kg/m })\end{array}$ & $111.5 \pm 18.7$ & $165.5 \pm 8.9$ & 1.000 \\
$\begin{array}{l}\text { Waist } \\
\text { circumference } \\
\text { (cm) }\end{array}$ & $121.6 \pm 8.8$ & $120.9 \pm 8.5$ & 0.016 \\
$\begin{array}{l}\text { Hip } \\
\text { circumference } \\
\text { (cm) }\end{array}$ & $126.7 \pm 11.7$ & $125.5 \pm 11.2$ & 0.168 \\
$\begin{array}{l}\text { Waist to hip ratio } \\
\text { Systolic blood } \\
\text { pressure (mm Hg) }\end{array}$ & $0.96 \pm 0.08$ & $0.97 \pm 0.08$ & 0.086 \\
$\begin{array}{l}\text { Diastolic blood } \\
\text { pressure (mm Hg) }\end{array}$ & $85.9 \pm 4.4$ & $87.3 \pm 3.4$ & 0.211 \\
\hline
\end{tabular}

*Data presented as mean \pm standard deviation $(\mathrm{SD}) ;{ }^{* *}$ data presented as median; ${ }^{* * *}$ Wilcoxon matched paired test

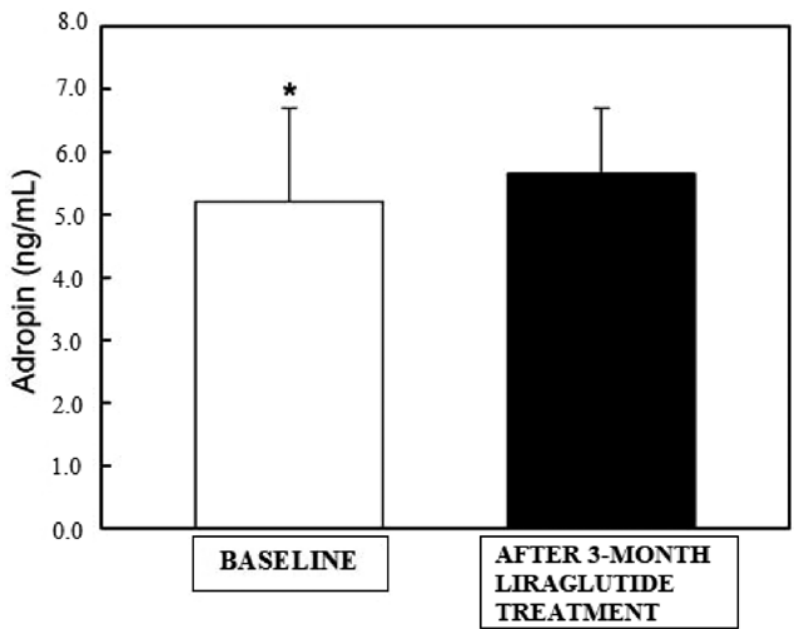

Fig. 1. Plasma adropin concentration - baseline and after 3-month liraglutide treatment.

After three months of liraglutide treatment, we observed changes in anthropometric parameters (Table 1). Analysis confirmed a significant decrease in both body weight and BMI; body weight was reduced from $111.5 \pm 18.7 \mathrm{~kg}$ to $109.2 \pm 17.5 \mathrm{~kg}(\mathrm{p}=0.016)$ and $\mathrm{BMI}$ from $40.9 \pm 7.3$ to $40.1 \pm 7.0 \mathrm{~kg} / \mathrm{m}^{2}(\mathrm{p}=0.021)$. Over these three months, systolic blood pressure decreased but not significantly. After 3-month liraglutide treat-
Table 2. Glucose metabolism parameters

\begin{tabular}{|l|l|l|l|}
\hline Variable & Baseline & $\begin{array}{l}\text { After 3 months } \\
\text { of treatment }\end{array}$ & $\mathrm{p}^{*}$ \\
\hline $\begin{array}{l}\text { Fasting insulin } \\
\text { (mU/L) }\end{array}$ & $17.79 \pm 6.53$ & $13.38 \pm 3.51$ & 0.002 \\
$\begin{array}{l}\text { Fasting blood } \\
\text { glucose } \\
(\mathrm{mmol} / \mathrm{L})\end{array}$ & $8.66 \pm 3.07$ & $7.41 \pm 2.21$ & 0.004 \\
$\begin{array}{l}\text { HbA } \\
\text { 1c } \%)\end{array}$ & $7.98 \pm 0.70$ & $7.26 \pm 0.36$ & 0.003 \\
HOMA-IR & $7.30 \pm 5.19$ & $4.52 \pm 2.61$ & 0.002 \\
\hline
\end{tabular}

Data presented as mean \pm standard deviation $(\mathrm{SD})$; *Wilcoxon matched paired test; HOMA-IR = Homeostatic Model Assessment of Insulin Resistance

Table 3. Biochemical parameters

\begin{tabular}{|l|l|l|l|}
\hline Variable & Baseline & $\begin{array}{l}\text { After 3 months } \\
\text { of treatment }\end{array}$ & $p^{*}$ \\
\hline $\begin{array}{l}\text { Triglycerides } \\
\text { (mmol/L) }\end{array}$ & $1.88 \pm 1.34$ & $1.78 \pm 1.14$ & 0.449 \\
$\begin{array}{l}\text { Cholesterol } \\
\text { (mmol/L) }\end{array}$ & $5.49 \pm 0.92$ & $5.45 \pm 0.83$ & 0.343 \\
$\begin{array}{l}\text { HDL } \\
\text { cholesterol } \\
(\mathrm{mmol} / \mathrm{L})\end{array}$ & $1.18 \pm 0.28$ & $1.27 \pm 0.27$ & 0.063 \\
$\begin{array}{l}\text { LDL } \\
\text { cholesterol } \\
\text { (mmol/L) }\end{array}$ & $3.39 \pm 0.71$ & $3.26 \pm 0.72$ & 0.082 \\
$\begin{array}{l}\text { AST }(\mathrm{U} / \mathrm{L}) \\
\text { ALT }(\mathrm{U} / \mathrm{L})\end{array}$ & $20.4 \pm 7.71$ & $21.2 \pm 8.12$ & 0.173 \\
$\begin{array}{l}\text { GGT }(\mathrm{U} / \mathrm{L}) \\
\text { Creatinine } \\
(\mu \mathrm{mol} / \mathrm{L})\end{array}$ & $30.70 \pm 22.32$ & $31.9 \pm 18.65$ & 0.102 \\
$\begin{array}{l}\text { Urea } \\
(\mathrm{mmol} / \mathrm{L})\end{array}$ & $79.09 \pm 23.29$ & $81.36 \pm 23.91$ & 0.230 \\
$\begin{array}{l}\text { Urate } \\
(\mu \mathrm{mol} / \mathrm{L})\end{array}$ & $390.02 \pm 1.12$ & $6.05 \pm 1.12$ & 0.476 \\
\hline
\end{tabular}

Data presented as mean \pm standard deviation $(\mathrm{SD})$; *Wilcoxon matched paired test: $\mathrm{HDL}=$ high-density lipoprotein; $\mathrm{LDL}=$ lowdensity lipoprotein; AST = aspartate transaminase; ALT = alanine transaminase; GGT = gamma-glutamyltransferase

ment, plasma adropin concentration increased significantly $(\mathrm{p}=0.003)$ as compared with the baseline (Fig. 1). Besides obesity reduction, disease control was remarkably improved. All the parameters of glucose metabolism improved significantly. Fasting plasma insulin level decreased from $17.79 \pm 6.53$ to $13.38 \pm 3.51$ 
$\mathrm{mU} / \mathrm{L}$ ( $\mathrm{p}=0.002$ ), fasting blood glucose level from $8.66 \pm 3.07$ to $7.41 \pm 2.21 \mathrm{mmol} / \mathrm{L}(\mathrm{p}=0.004)$ and $\mathrm{HbA}_{1 \mathrm{c}}$ from $7.98 \pm 0.70$ to $7.26 \pm 0.36 \%(\mathrm{p}=0.003)$. Insulin resistance presented as HOMA-IR improved significantly and its value decreased from $7.30 \pm 5.19$ to 4.52 $\pm 2.61(\mathrm{p}=0.002)$ (Table 2).

Our study showed improvement in lipid profile (cholesterol, triglycerides, low-density lipoproteins), but these results did not show significant change. Additionally, we noticed improvement in liver function through a decrease of aspartate transaminase (AST), alanine transaminase (ALT) and gamma-glutamyltransferase (GGT) levels but these results were not statistically significant. Kidney function was slightly improved, although creatinine, urea and urate levels did not show significant change (Table 3 ).

\section{Discussion}

Considering the fact that obesity and insulin resistance play key roles in the development of T2DM, therapeutic options leading to the resolution of these issues may be of utmost importance $e^{3,531,32}$. Identifying adropin as a marker of endothelial cell dysfunction that is found to be lower in T2DM patients ${ }^{9,10}$ and that liraglutide may afford protection against endothelial cell dysfunction, which is an early abnormality in diabetic vascular disease ${ }^{33}$, led us to explore adropin levels in T2DM patients treated with liraglutide. Therefore, this study is of great importance because it is the first one to compare the effects of liraglutide treatment on plasma adropin concentration and parameters of insulin resistance in T2DM patients.

Kumar et al. hypothesize that adropin is involved in regulation of metabolic homeostasis and that its deficiency has a negative effect on glucose homeostasis and carries an increased risk of developing insulin resistance and T2DM progression ${ }^{6-8}$. Our study provided data on the effect of 3-month liraglutide treatment applied once daily in combination with metformin in male obese patients with T2DM. We showed that liraglutide treatment led to a significantly higher plasma adropin concentration ( $p=0.003)$, one of the regulators of endothelial cell dysfunction in T2DM ${ }^{12-14}$. Hence, elevated plasma adropin concentration could partially explain cardiovascular benefits and protection provided by liraglutide. Furthermore, the application of liraglutide and higher adropin concentration were associ- ated with decreased insulin resistance parameters. Consequently, the levels of fasting plasma glucose $(p=0.004)$, fasting plasma insulin $(p=0.002)$ and HOMA-IR ( $\mathrm{p}=0.002)$ decreased significantly after three months of liraglutide treatment.

Recent studies demonstrated that patients with T2DM treated with GLP-1 RA improved their glycemic control and had modest weight loss ${ }^{34}$. Other studies showed that liraglutide treatment significantly decreased weight and improved insulin resistance ${ }^{32}$. Our results also confirmed that this treatment led to significant weight loss $(\mathrm{p}=0.016)$, decreased BMI ( $\mathrm{p}=$ $0.021)$ and improved insulin resistance parameters $(p=0.002)$. Decreased adiposity could be the outcome of early satiety and slower gastric emptying caused by liraglutide ${ }^{20}$. Following the previous information, not only BMI was significantly reduced, but also $\mathrm{HbA}_{1 \mathrm{c}}$ $(p=0.003)$, which was shown in previous studies ${ }^{32,34,35}$.

Furthermore, we observed a small decrease in systolic blood pressure, but it was not statistically significant, unlike several other studies that investigated liraglutide effect ${ }^{36,37}$. Considering the fact that our study was shorter (12 weeks) than the mentioned studies (24 weeks), we think that our results would probably be of the same relevance with longer study duration. In addition to a significantly decreased level of systolic blood pressure, liraglutide appears to improve the levels of cholesterol, low-density lipoprotein cholesterol and triglycerides ${ }^{20}$. Our study showed improvement in lipid profile (cholesterol, triglycerides, low-density lipoproteins) and systolic blood pressure, but did not demonstrate statistical significance compared to other studies. This may be due to the lower baseline BMI $\left(33.49 \pm 5.15 \mathrm{~kg} / \mathrm{m}^{2}\right)^{35}$ when compared to our patient BMI $\left(40.9 \pm 7.3 \mathrm{~kg} / \mathrm{m}^{2}\right)$.

Another interesting finding was a slight reduction in ALT, AST and GGT concentrations. This GGT result found in our study was similar to the previously reported results, but ALT and AST results in our study were not in concordance with other studies. These differences may have been due to the lower baseline BMI level $\left(30.1 \mathrm{~kg} / \mathrm{m}^{2}\right)$ and lower body weight in the abovementioned study.

\section{Conclusions}

In conclusion, treating male obese T2DM patients with liraglutide results in a significantly higher plasma 
adropin concentration, significant weight loss and improved parameters of insulin resistance, i.e. decreased fasting plasma insulin and glucose levels and decreased HOMA-IR. Liraglutide treatment also ameliorates systolic blood pressure, lipid profile and kidney function, but these results were not statistically significant. Additional studies of longer duration and larger number of participants are needed so we could have more precise and reliable results.

\section{References}

1. Cho NH, Shaw JE, Karuranga S, et al. IDF Diabetes Atlas: Global estimates of diabetes prevalence for 2017 and projections for 2045. Diabetes Res Clin Pract. 2018;138:271-81. https://doi.org/10.1016/j.diabres.2018.02.023

2. Okamura T, Hashimoto Y, Hamaguchi M, et al. Ectopic fat obesity presents the greatest risk for incident type 2 diabetes: a population-based longitudinal study. Int J Obes (Lond). 2019; 43(1):139-48. https://doi.org/10.1038/s41366-018-0076-3

3. Al-Goblan AS, Al-Alfi MA, Khan MZ. Mechanism linking diabetes mellitus and obesity. Diabetes Metab Syndr Obes. 2014;7:587-91. https://doi.org/10.2147/DMSO.S67400

4. Scott RA, Fall T, Pasko D, et al. Common genetic variants highlight the role of insulin resistance and body fat distribution in type 2 diabetes, independently of obesity. Diabetes. 2014; 63(12):4378-87. https://doi.org/10.2337/db14-0319

5. American Diabetes Association. Standards of medical care in diabetes - 2018. Diabetes Care. 2018;41(Suppl 1):S1-S2. https: //doi.org/10.2337/dc10-S011

6. Kumar KG, Zhang J, Gao S, et al. Adropin deficiency is associated with increased adiposity and insulin resistance. Obesity (Silver Spring). 2012;20(7):1394-402. https://doi.org/10.1038/ oby.2012.31

7. Bozic J, Borovac JA, Galic T, et al. Adropin and inflammation biomarker levels in male patients with obstructive sleep apnea: a link with glucose metabolism and sleep parameters. J Clin Sleep Med. 2018;14(7):1109-18. doi:10.5664/jcsm.7204

8. Mierzwicka A, Bolanowski M. New peptides players in metabolic disorders. Postepy Hig Med Dosw (Online). 2016;70(0): 881-6.

9. Lovren F, Pan Y, Quan A, et al. Adropin is a novel regulator of endothelial function. Circulation. 2010;122:S185-92. https:// doi.org/10.1161/CIRCULATIONAHA.109.931782

10. Zang H, Jiang F, Cheng X, et al. Serum adropin levels are decreased in Chinese type 2 diabetic patients and negatively correlated with body mass index. Endocr J. 2018;65(7):685-91. https://doi.org/10.1507/endocrj.EJ18-0060

11. Li L, Xie W, Zheng XL, et al. A novel peptide adropin in cardiovascular diseases. Clin Chim Acta. 2016;453:107-13. https: //doi.org/10.1016/j.cca.2015.12.010
12. Celik A, Balin M, Kobat MA, et al. Deficiency of a new protein associated with cardiac syndrome $\mathrm{X}$, called adropin. Cardiovasc Ther. 2013;31:174-8. https://doi.org/10.1111/1755-5922.12025

13. Topuz M, Celik A, Aslantas T, et al. Plasma adropin levels predict endothelial dysfunction like flow-mediated dilatation in patients with type 2 diabetes mellitus. J Investig Med. 2013:61(8):1161-4. https://doi.org/10.2310/JIM.0000000000 000003

14. Beckman JA, Creager MA, Libby P. Diabetes and atherosclerosis: epidemiology, pathophysiology, and management. JAMA. 2002;287:2570-81.

15. Barnett AH. The role of GLP-1 mimetics and basal insulin analogues in type 2 diabetes mellitus: guidance from studies of liraglutide. Diabetes Obes Metab. 2012;14(4):304-14. https:// doi.org/10.1111/j.1463-1326.2011.01523.x

16. Derosa G, Maffioli P. GLP-1 agonists exenatide and liraglutide: a review about their safety and efficacy. Curr Clin Pharmacol. 2012;7:214-28.

17. National Institute for Health and Clinical Excellence. NICE technology appraisal guidance 203: liraglutide for the treatment of type 2 diabetes mellitus 2010. Available at: http:// guidance.nice.org.uk. Accessed: January 28, 2015.

18. Lovshin JA, Drucker DJ. Incretin-based therapies for type 2 diabetes mellitus. Nat Rev Endocrinol. 2009;5:262-9. https:// doi.org/10.1038/nrendo.2009.48

19. Baretic M. Glucagon-like peptide- 1 affects taste perception differently in women: a randomized, placebo-controlled crossover study. Acta Clin Croat. 2019;58(2):240-7. https://doi. org/10.20471/acc.2019.58.02.06

20. Niswender K, Pi-Sunyer X, Buse J, et al. Weight change with liraglutide and comparator therapies: an analysis of seven phase 3 trials from the liraglutide diabetes development programme. Diabetes Obes Metab. 2013;15(1):42-54. https:/doi.org/10.11 11/j.1463-1326.2012.01673

21. Marso SP, Poulter NR, Nissen SE, et al. Design of the Liraglutide Effect and Action in Diabetes: Evaluation of cardiovascular outcome Results (LEADER) trial. Am Heart J. 2013;166 (5):823-30.e5

22. Marso SP, Daniels GH, Brown-Frandsen K, et al. Liraglutide and cardiovascular outcomes in type 2 diabetes. N Engl J Med. 2016;375:311-22. https:/doi.org/10.1056/NEJMoa1603827

23. Pennsylvania Department of Health. Anthropometric Training Manual Part 1: Anthropometric Technique and Data Entry June 2010 Division of Women, Infants and Children (WIC). Available at: http://www.nal.usda.gov/wicworks/Sharing_Center/PA/Anthro/lib/pdf/Anthropometric_Training_Manual.pdf, Accessed: January 30, 2015.

24. National Health and Nutrition Examination Survey (NHANES). Anthropometry Procedures Manual. CDC, 2013. Available at: http://www.cdc.gov/nchs/data/nhanes/nhanes_ 13_14/2013_Anthropometry.pdf. Accessed: January 30, 2015

25. World Health Organization (WHO). Physical status: the use and interpretation of anthropometry. Report of a WHO Expert Committee. WHO Technical Report Series No. 854. Genewa: WHO; 1995. 
26. Shen W, Punyanitya M, Chen J, et al. Waist circumference correlates with metabolic syndrome indicators better than percentage fat. Obesity (Silver Spring). 2006;14:727-36.

27. Lemieux I, Poirier P, Bergeron J, et al. Hypertriglyceridemic waist: a useful screening phenotype in preventive cardiology? Can J Cardiol. 2007;23(Suppl B):23B-31B.

28. James WPT. Epidemiology of obesity. In: Chadwick DJ, Cardew GC, eds. The Origin and Consequences of Obesity. Chichester, Wiley: Ciba Foundation Symposium 201,1996;1-16.

29. Molarius A, Tuomilehto J, Kuulasmaa K, for the WHO MONICA Project. Quality Assessment of Data on Hypertension Control in the WHO MONICA Project. MONICA Data Centre, National Public Health Institute, Helsinki, Finland; Department of Epidemiology and Health Promotion, National Public Health Institute, Helsinki, Finland. 1998. Accessed: January 31, 2015.

30. Ogedegbe G, Pickering T. Principles and techniques of blood pressure measurement. Cardiol Clin. 2010;28(4):571-86.

31. Li S, Zhao JH, Luan J, et al. Genetic predisposition to obesity leads to increased risk of type 2 diabetes. Diabetologia. 2011; 54(4):776-82. https://doi.org/10.1007/s00125-011-2044-5.

32. Kim SH, Abbasi F, Lamendola C, et al. Benefits of liraglutide treatment in overweight and obese older individuals with prediabetes. Diabetes Care. 2013;36(10):3276-82. https://doi.org $/ 10.2337 / \mathrm{dc} 13-0354$
33. Gaspari T, Liu H, Welungoda I, et al. A GLP-1 receptor agonist liraglutide inhibits endothelial cell dysfunction and vascular adhesion molecule expression in an ApoE-/- mouse model. Diab Vasc Dis Res. 2011;8(2):117-24. https://doi.org/10.1177 /1479164111404.257

34. Vilsbøll T, Christensen M, Junker AE, et al. Effects of glucagon-like peptide-1 receptor agonists on weight loss: systematic review and meta-analyses of randomised controlled trials. BMJ. 2012;344:d7771. https://doi.org/10.1136/bmj.d7771

35. Díaz-Soto G, de Luis DA, Conde-Vicente R, et al. Beneficial effects of liraglutide on adipocytokines, insulin sensitivity parameters and cardiovascular risk biomarkers in patients with type 2 diabetes: a prospective study. Diabetes Res Clin Pract. 2014; 104(1):92-6. https://doi.org/10.1016/j.diabres.2014.01.019

36. Fonseca V, Falahati A, Zychma M, et al. A meta-analysis of six clinical trials demonstrates that the once-daily human GLP-1 analogue liraglutide reduces systolic blood pressure. Diabetologia. 2009;52(1):S299.

37. Marre M, Shaw J, Brändle M, et al. Liraglutide, a once-daily human GLP-1 analogue, added to a sulphonylurea over 26 weeks produces greater improvements in glycaemic and weight control compared with adding rosiglitazone or placebo in subjects with type 2 diabetes (LEAD-1 SU). Diabet Med. 2009; 26(3):268-78.

\section{Sažetak \\ ADROPIN - POTENCIJALNI ČIMBENIK KARDIOVASKULARNE SIGURNOSTI U MUŠKARACA OBOLJELIH OD ŠEĆERNE BOLESTI TIP 2 LIJEČENIH LIRAGLUTIDOM}

\section{T. Tičinović Kurir, T. Miličević, A. Novak, M. Vilović i J. Božić}

Cilj je bio usporediti plazmatske vrijednosti adropina i parametre inzulinske rezistencije kod pretilih muškaraca koji boluju od šećerne bolesti tip 2 (ŠBT2) prije i nakon 3 mjeseca primjene liraglutida. U ovoj intervencijskoj studiji sudjelovalo je 15 pretilih muškaraca koji boluju od ŠBT2 s indeksom tjelesne mase (ITM) $>35 \mathrm{~kg} / \mathrm{m}^{2}$, loše reguliranom bolešću i HbA $>7,5 \%$. Ispitanici su prethodno u terapiji imali dva peroralna antidijabetična lijeka. Nakon uključenja u studiju terapija im je modificirana na metformin i liraglutid tijekom tri mjeseca. Nakon primjene liraglutida kod ispitanika je zamijećeno smanjenje tjelesne mase (sa 111,5 $\pm 18,7$ na 109,2 $\pm 17,5 \mathrm{~kg}, \mathrm{p}=0,016$ ) i ITM ( $40,9 \pm 7,3$ na 40,1 $\pm 7,0 \mathrm{~kg} / \mathrm{m}^{2}, \mathrm{p}=0,021$ ), dok su plazmatske vrijednosti adropina bile značajno povišene $(\mathrm{p}=0,003)$. Zamijećeno je sniženje vrijednosti inzulina natašte (sa $17,79 \pm 6,53$ na $13,38 \pm 3,51 \mathrm{mU} / \mathrm{L}, \mathrm{p}=0,002)$, glukoze natašte (s $8,66 \pm 3,07$ na 7,41 $\pm 2,21 \mathrm{mmol} / \mathrm{L}, \mathrm{p}=0,004)$ te $\mathrm{HbA}_{1 \mathrm{c}}$ (sa $7,98 \pm 0,70 \%$ na $7,26 \pm 0,36 \%$, $p=0,003$ ). HOMA-IR se značajno smanjio (sa 7,30 $\pm 5,19$ na 4,52 $\pm 2,61, p=0,002$ ). Također su zabilježene niže vrijednosti sistoličkog arterijskog tlaka, bolji lipidni profil te poboljšanje jetrene i bubrežne funkcije, iako ne statistički značajno. Primjena liraglutida u pretilih muškaraca koji boluju od ŠBT2 rezultira statistički značajno višim razinama plazmatskog adropina, značajnim smanjenjem tjelesne težine i poboljšanjem svih parametara inzulinske rezistencije, tj. sniženjem plazmatskog inzulina i glukoze natašte te nižim HOMA-IR.

Ključne riječi: Šećerna bolest tip 2; Inzulinska rezistencija; Pretilost; Adropin; Liraglutid; Endotelna disfunkcija 